\title{
2012: Ponto de Chegada, Ponto de Partida
}

Antonio Fernando de C. A. Beraldo ${ }^{1}$

Eduardo Magrone ${ }^{2}$

Tailiny Paula Ventura ${ }^{3}$

As universidades públicas federais se movimentam para atender à Lei das Cotas, ou para consolidar as políticas de inclusão já adotadas pela maioria delas. A convergência, em 2012, de dois importantes vetores nas políticas públicas do ensino superior - a pressão do movimento negro pela implantação de políticas afirmativas, e a expansão das universidades promovida pelo REUNI, após anos de medidas restritivas do governo FHC -, foi eficaz na inclusão dos menos favorecidos, porém, ao mesmo tempo, acentuou as imensas deficiências do ensino básico. Isto faz com que uma parcela dos alunos que ingressaram pelas cotas tenha um rendimento acadêmico muito abaixo dos demais. Há muito que fazer, não só em termos de amparo material, mas, principalmente, de medidas pedagógicas que diminuam a evasão e façam valer o investimento que a sociedade faz, inserindo bons profissionais no mercado de trabalho.

Palavras-chave: universidades federais; políticas de cotas; movimento negro; REUNI.

\section{2: End Point, Starting Point}

\footnotetext{
${ }^{1}$ Professor do Departamento de Estatística da UFJF, Mestre em Educação e doutorando em Ciências Sociais, em Políticas Públicas em Educação (antonio.beraldo@ufjf.edu.br)

${ }^{2}$ Pró Reitor de Graduação da UFJF, professor da Faculdade de Educação da UFJF, doutor em Ciências Sociais (eduardo.magrone@ufff.edu.br).

${ }^{3}$ Graduanda em Ciências Econômicas - UFJF (tailinyventura@hotmail.com).
} 


\section{Abstract}

Public federal universities move to the Law of the Quotas into practice, or to consolidate their own policies of inclusion. The convergence, in 2012, of two important vectors on public policies in higher education - the pressure by the Black Movement for affirmative action policies and the increase in the number of universities promoted by the Federal Government's Program to Support Plans to Restructure and Expansion of the Brazilian Federal Universities (REUNI), after years of restrictive rules of President Fernando Henrique Cardoso's tenure, FHC government, was successful in the admission of the least favored, but, at the same time, It emphasized the major efficiencies of the basic educational level. A proportion of students who were admitted through the quota system has very low academic performances. There is much to do about them, not only in terms of financial support, but, mainly, in terms of pedagogical procedures in order to diminish their attrition rates and also to justify the investment society has made, so as to prepare them to be competent professionals for the labor market.

Keywords: federal universities; quota policies; Black Movement; REUNI.

\section{A Lei das Cotas e o REU N I}

Em agosto de 2012 foi sancionada a Lei ${ }^{\circ}$ 12.711/2012, chamada Lei das Cotas, que garante a reserva de $50 \%$ das matrículas por curso e turno nas instituições federais de ensino superior (universidades e institutos federais de educação, ciência e tecnologia) a alunos provenientes de escolas públicas de ensino médio. A outra metade das vagas é destinada aos demais candidatos, nomeada esta parte de "ampla concorrência". 0 percentual de vagas reservadas a cotistas é também dividido em duas metades, segundo a renda familiar bruta do candidato, acima ou abaixo da renda de corte, de um salário mínimo e meio - é 
o caráter "social" desta política. E, dentro destas subdivisões pela renda, é estipulado outro percentual mínimo de reserva de vagas, referente à proporção de pretos, pardos e indígenas do estado, conforme apurado no último censo feito pelo IBGE - o caráter "racial" da lei. Estes percentuais serão aplicados gradativamente, até que, em 2016, todas as instituições federais completem estas cotas. No momento da Lei, 36 das 59 universidades federais (61\%) tinham políticas de cotas raciais e/ou sociais, 32 (54\%) tinham cotas para estudantes oriundos de escolas públicas, 25 (42\%) algum tipo de cota racial, 21 (36\%) cotas para negros e pardos, 19 (32\%) cotas para índios, 7 tinham cotas para deficientes, 1 tinha cota para quilombolas ${ }^{4}$.

A divisão das vagas nas IFES, que não corresponde às proporções encontradas no país neste momento, foi feita atendendo às demandas de alguns segmentos da sociedade e do governo, no sentido de aumentar o percentual de vagas nas instituições federais destinadas a alunos oriundos de escolas públicas, de contemplar as reivindicações dos movimentos negros por vagas específicas para pretos e pardos, e de pressões sociais por vagas para índios.

A expansão das vagas e matrículas no ensino superior, durante a chamada "década da inclusão", foi conduzida, em sua maior parte, pela esfera particular, que evoluiu de 68,4\% das matrículas em 2001 para 73,1\% em 2012, recuperando-se da crise de 2008-09 (crescimento de -0,9\%) graças ao ProUni - Programa Universidade para Todos, com 2 milhões de bolsas concedidas entre 2005-13, e à explosão da modalidade a distância, que chegou a 932 mil matrículas em 2012 (84\% do total). Atualmente, 3 em cada 4 alunos do ensino superior frequentam os cursos das

4 Levantamento feito pelo portal G1, vide http://g1.globo.com/educacao/ noticia/2012/04/423-das-universidades-federais-do-pais-tem-cotas-para-negros-e-indios.html A UFPA abriu no vestibular de 2013, 2 vagas para quilombolas. A UFT, em novembro de 2012 , reservou $5 \%$ das vagas para quilombolas. 
IES particulares.

No governo FHC (1995-2002), com a "reforma do estado", que não fez a reposição das vagas de docentes que se aposentavam - e até induziu aposentadorias precoces -, e extinguiu centenas de cargos no serviço público superior, comprimindo salários e desmotivando o trabalho universitário, as IFES passaram a funcionar com um contingente cada vez maior de docentes substitutos e funcionários terceirizados. Isto, junto com as greves que se sucediam e se alongavam por meses, comprometeu em grande escala o ambiente acadêmico, mas criou a vontade e a expectativa crescentes que um novo governo, politicamente voltado para reformas e avanços sociais, fosse atender as demandas por crescimento das IFES, não só internamente, como por parte de uma classe média que se reforçava numérica e economicamente com a prosperidade da "década de inclusão", e queria ascender ao nível universitário.

Quando o governo Lula começou ${ }^{5}$, as universidades públicas federais tinham cerca de 528 mil matrículas e ofereciam menos de 110 mil vagas nos vestibulares, e a relação candidato-vaga era de 10,6. Nos primeiros anos daquele governo, o crescimento das matrículas não chegava a $4 \%$ ao ano, e o das vagas oscilava desordenadamente, entre 5\% e 13\%. Para romper com esta quase estagnação, e expandir de maneira coordenada as IFES, o governo federal lançou um projeto ambicioso, o Programa de Apoio a Planos de Reestruturação e Expansão das Universidades Federais - o REUNI.

O REUNI foi instituído pelo Decreto no 6.096, de 24 de abril de

\footnotetext{
${ }^{5}$ Neste artigo, o foco será apenas nas IFES, sem que se discorra sobre o ProUni e a ampliação do Fies, outras ações muito importantes do governo Lula em termos de políticas públicas de inclusão no ensino superior.
} 
2007, sendo uma das ações que integram o Plano de Desenvolvimento da Educação (PDE). Em linhas gerais, o plano propõe um aumento na oferta de vagas das IFES, e consequente aumento no número de matrículas (ampliação do acesso e permanência na educação superior, no nível de graduação), tendo como meta global a elevação gradual da taxa de conclusão média dos cursos de graduação presenciais para noventa por cento e da relação de alunos de graduação em cursos presenciais por professor para dezoito, ao final de cinco anos, a contar do início de cada plano. (BRASIL, 2007). Além disso, detalha as diretrizes

Redução das taxas de evasão, ocupação de vagas ociosas e aumento de vagas de ingresso, especialmente no período noturno; ampliação da mobilidade estudantil, com a implantação de regimes curriculares e sistemas de títulos que possibilitem a construção de itinerários formativos, mediante o aproveitamento de créditos e a circulação de estudantes entre instituições, cursos e programas de educação superior; revisão da estrutura acadêmica, com reorganização dos cursos de graduação e atualização de metodologias de ensino-aprendizagem, buscando a constante elevação da qualidade; diversificação das modalidades de graduação, preferencialmente não voltadas à profissionalização precoce e especializada; ampliação de políticas de inclusão e assistência estudantil; e articulação da graduação com a pós-graduação e da educação superior com a educação básica. (BRASIL, 2007)

Em contrapartida,

O Ministério da Educação destinará ao Programa recursos financeiros, que serão reservados a cada universidade federal, (...) [e seus] respectivos planos de reestruturação, a fim de suportar as despesas decorrentes das iniciativas propostas, especialmente no que respeita a construção e readequação de infraestrutura e equipamentos necessárias à realização dos objetivos do Programa; compra de bens e serviços necessários ao funcionamento dos novos regimes 
acadêmicos; e despesas de custeio e pessoal associadas à expansão das atividades decorrentes do plano de reestruturação. (BRASIL, 2007)

O REUNI foi claramente inspirado no movimento que se chamou "Universidade Nova", resultante do Processo de Bolonha ${ }^{6}$, que é a criação de um sistema de educação superior em que alguns países da Europa unem suas políticas educacionais de forma a criar um "autêntico locus supranacional de definição de políticas educacionais de caráter transnacional, com particular destaque, atualmente, para a educação superior." (LIMA, AZEVEDO e CATANI, 2008, p.3). Esta é uma ação sem precedentes, dado que o sistema de educação superior na Europa vem desde a criação da própria Universidade de Bolonha, no século XI, constituindo-se em instituições com histórias, culturas, tradições e tendências muito diversas e específicas, de caráter nacional ou regional. Contudo,

Uma Europa de Conhecimento é, agora, amplamente reconhecida como um fator insubstituível para o crescimento social e humano, e como um componente indispensável na consolidação e enriquecimento da cidadania europeia, capaz de fornecer aos seus cidadãos as competências necessárias diante das mudanças do novo milênio, junto com o reconhecimento de valores compartilhados e o pertencimento a um espaço social e cultural comum. (...) A importância da Educação e da cooperação educacional no desenvolvimento e fortalecimento de sociedades estáveis, pacíficas e democráticas é reconhecida universalmente. (BOLOGNA, 2010, tradução dos autores).

${ }^{6}$ O Processo, ou Declaração de Bolonha é declaração conjunta dos Ministros da Educação europeus, em 19 de Junho de 1999. A esta declaração inicial, sucederam-se as declarações produzidas em diversas cidades da Europa, como Praga (2001), Berlin (2003), Bergen (2005), Londres (2007), Louvain (2009) e Budapeste-Viena (2010). 
Transposto para o Brasil, o Processo/REUNI introduz as seguintes alterações:

- Regime de três ciclos, a saber: Primeiro Ciclo, um Bacharelado Interdisciplinar, com disciplinas básicas de formação universitária geral, preparatório para a etapa seguinte; Segundo ciclo, de formação profissional em licenciaturas e carreiras específicas; Terceiro Ciclo, com os cursos de pós-graduação. Na Declaração de Bolonha original (1999), eram 2 ciclos: "um primeiro ciclo útil para o mercado de trabalho, de uma duração mínima de 3 anos, e um segundo ciclo (mestrado) dependente da conclusão do primeiro ciclo" (EUR-LEX, 2010).

- Mobilidade acadêmica: com a introdução do SISU (Sistema de Seleção Unificada) e a utilização da pontuação do ENEM em substituição aos vestibulares próprios das instituições. Em tese uma pessoa poderia ingressar em IFES de outras cidades e estados, e, já estudando em uma IFES, poderia trocar de instituição havendo vagas disponíveis. Na Declaração de Bolonha, era instituída a promoção da mobilidade dos estudantes, dos professores e dos investigadores [pesquisadores] através da supressão de todos os obstáculos à liberdade de circulação. (EUR-LEX, 2010)

Assim, segundo os tópicos anteriores, a nova estrutura dos cursos nas universidades pode ser esquematizada da seguinte forma:

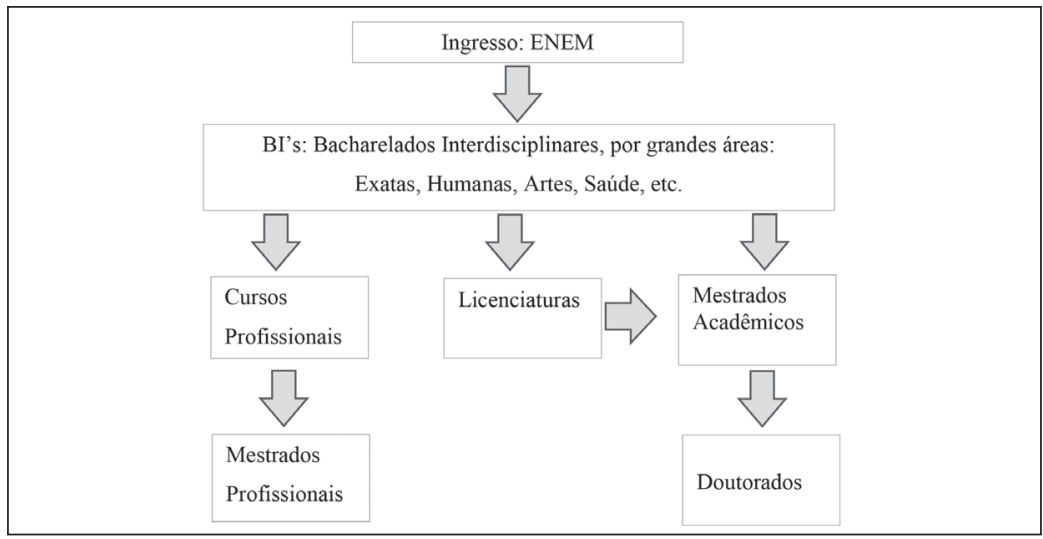

A expansão das matrículas e dos ingressantes em instituições públicas de ensino superior no período 2001-2012 é descrita na 
tabela seguinte:

Tabela 1 - Evolução Percentual, Matrículas e Ingressantes, Esfera Pública 2001-2012.

\begin{tabular}{l|r|r|r|r|r|r}
\hline \multirow{2}{*}{ Ano } & \multirow{2}{*}{ Matrículas $^{\mathbf{1}}$} & \multicolumn{2}{|c|}{ Evolução Percentual } & Ingressantes & \multicolumn{2}{|c}{ Evolução Percentual } \\
\cline { 4 - 7 } & & $\mathbf{A}$ & $\mathbf{B}$ & & $\mathbf{A}$ & $\mathbf{B}$ \\
\hline 2002 & 1.051 .655 & 12,0 & 12,0 & 320.354 & 31,0 & 31,0 \\
2003 & 1.136 .370 & 8,1 & 21,0 & 321.689 & 0,4 & 31,5 \\
2004 & 1.178 .328 & 3,7 & 25,5 & 357.979 & 11,3 & 46,3 \\
2005 & 1.192 .189 & 1,2 & 26,9 & 331.365 & $-7,4$ & 35,5 \\
2006 & 1.209 .304 & 1,4 & 28,8 & 335.767 & 1,3 & 37,3 \\
2007 & 1.240 .968 & 2,6 & 32,1 & 336.223 & 0,1 & 37,4 \\
2008 & 1.273 .965 & 2,7 & 35,6 & 352.615 & 4,9 & 44,1 \\
2009 & 1.351 .168 & 6,1 & 43,9 & 379.134 & 7,5 & 55,0 \\
2010 & 1.461 .696 & 8,2 & 55,6 & 435.710 & 14,9 & 78,1 \\
2011 & 1.595 .391 & 9,1 & 69,9 & 456.635 & 4,8 & 86,7 \\
2012 & 1.715 .752 & 7,5 & 82,7 & 499.370 & 9,4 & 104,1 \\
\hline
\end{tabular}

Fonte: INEP, 2013, dados processados pelos autores.

Notas: 1 - Exclui Ensino A Distância.

2. A - percentual sobre o ano anterior, B - percentual sobre 2001

Pelos dados da tabela anterior, pode-se perceber a evolução irregular de ambas as variáveis. As matrículas em instituições públicas tem uma taxa de evolução declinante de 2002 a 2005/6, e recuperam o índice de crescimento a partir de 2007, atingindo uma taxa máxima em 2011, porém não se igualando ao verificado no começo do período (2002). Entre 2001 e 2012, o número de matrículas em instituições públicas cresceu 83\%.

Quanto ao número de ingressantes, com uma evolução ainda mais irregular, o percentual mínimo de evolução também ocorre em 2005, com uma taxa negativa. A partir de 2008, com o REUNI, o crescimento é mais vigoroso, ao ponto de terminar o período duplicando o número de ingressantes, que atinge meio milhão de pessoas. Especificamente nas universidades federais, a evolução é a seguinte:

Tabela 2 - Evolução das Matrículas em Universidades Federais 
Antonio Fernando de C. A. Beraldo; Eduardo Magrone; Tailiny Paula Ventura

\begin{tabular}{|c|c|c|c|}
\hline \multirow{2}{*}{ Ano } & \multirow{2}{*}{ Matrículas (x 1.000) } & \multicolumn{2}{|c|}{ Evolução Percentual } \\
\hline & & $\mathbf{A}$ & $\mathbf{B}$ \\
\hline 2001 & 472 & - & - \\
\hline 2002 & 501 & 6,1 & 6,1 \\
\hline 2003 & 528 & 5,4 & 11,9 \\
\hline 2004 & 533 & 0,9 & 12,9 \\
\hline 2005 & 550 & 3,2 & 16,5 \\
\hline 2006 & 556 & 1,1 & 17,8 \\
\hline 2007 & 579 & 4,1 & 22,7 \\
\hline 2008 & 601 & 3,8 & 27,3 \\
\hline 2009 & 696 & 15,8 & 47,5 \\
\hline 2010 & 763 & 9,6 & 61,7 \\
\hline 2011 & 842 & 10,4 & 78,4 \\
\hline 2012 & 886 & 5,2 & 87,7 \\
\hline
\end{tabular}

Fonte: INEP, 2013, dados processados pelos autores.

Notas: 1 - Exclui Ensino A Distância

2. A - percentual sobre o ano anterior, B - percentual sobre 2001

Como se vê na Tabela 3, entre 2008 e 2012, as matrículas nas universidades federais tem um crescimento acumulado de $60 \%$, mais do que o dobro do período 2001-2007, o que mostra a eficácia do REUNI. O programa REUNI surte efeito, principalmente, na quantidade de vagas oferecidas no Vestibular:

Tabela 3 - Evolução do número de vagas no Vestibular em Universidades Federais e candidatos inscritos (2004-2011)

\begin{tabular}{l|r|r|r|r|r|r|r}
\hline \multirow{2}{*}{ Ano } & \multicolumn{3}{|c|}{ Vagas (x 1.000) } & \multicolumn{3}{c|}{ Candidatos (x 1.000) } & \multirow{2}{*}{ C/V } \\
\cline { 2 - 6 } & & $\mathbf{A}$ & $\mathbf{B}$ & & $\mathbf{A}$ & $\mathbf{B}$ & \\
\hline 2004 & 110 & - & - & 1.171 & - & - & 10,6 \\
2005 & 116 & 5,5 & 5,5 & 1.179 & 0,7 & 0,7 & 10,2 \\
2006 & 132 & 13,8 & 20,0 & 1.188 & 0,8 & 1,5 & 9,0 \\
2007 & 139 & 5,3 & 26,4 & 1.189 & 0,1 & 1,5 & 8,6 \\
2008 & 151 & 8,6 & 37,3 & 1.234 & 3,8 & 5,4 & 8,2 \\
2009 & 187 & 23,8 & 70,0 & 1.177 & $-4,6$ & 0,5 & 6,3 \\
2010 & 218 & 16,6 & 98,2 & 1.937 & 64,6 & 65,4 & 8,9 \\
2011 & 231 & 6,0 & 110,0 & 2.978 & 53,7 & 154,3 & 12,9 \\
2012 & 240 & 3,9 & 118,2 & 3.804 & 27,7 & 224,9 & 15,9 \\
\hline
\end{tabular}

Fonte: INEP, 2013, dados processados pelos autores.

Notas: C/V - Relação candidato/vaga; A - percentual sobre o ano anterior; B - percentual sobre 2001.

Não inclui Ensino a Distância 
0 crescimento acumulado de ofertas de vagas a partir de 2008 chegou a $80 \%$, embora não alcançasse a meta estipulada (270 mil). No entanto, o número de candidatos, depois de ligeira queda em 2009, mais que dobrou, chegando a 3,8 milhões em 2012. 0 aumento expressivo do número de egressos do Ensino Médio que tenta uma vaga em uma universidade pública não decorre apenas da diminuição da evasão e da gratuidade dos cursos, mas da ampliação das oportunidades - não só pela política de cotas, mas pela criação de novas universidades federais, pela expansão dos cursos noturnos e pela interiorização dos cursos universitários, e, na maioria das regiões do país, pelo conceito que gozam as IFES, que resulta num maior valor conferido ao diploma e, teoricamente, num incremento da empregabilidade do egresso. Assim, é formado o lastro para a implantação da política de cotas, que é abordada na seção seguinte.

\section{M ovimento negro, cotas raciais e a AD PF 186/D F}

O ingresso de negros nas instituições públicas de ensino superior se deu muito mais por conta do REUNI do que pelo estabelecimento da reserva de vagas. Este novo cenário, em que são ofertadas 240 mil vagas nas universidades públicas (2012), é o ponto de partida para outra trajetória disposta pelas ações afirmativas no país, um marco no esforço para diminuir as desigualdades do Brasil. Em 2000, os percentuais de pretos (2,3\%) e pardos $(2,2 \%)$ que frequentavam o ensino superior era bem menor do que o de brancos (8,1\%).Outro exemplo: um dos principais indicadores, que é o percentual de estudantes entre 18 e 24 anos no ensino superior, salta de 27\% (2001) para 51\% (2011), mas não evolui da mesma forma para os negros: 10,2\% (2001) para 35,8\% (2011) - o percentual de brancos nesta faixa etária, na universidade, é quase o dobro, $68 \%$.

${ }^{7}$ Dados da PNAD de 2010, ver também IBGE, 2012, dados processados pelos autores. 
Em termos de Políticas Públicas, principalmente sob o enfoque da inclusão dos negros nas universidades, a Lei das Cotas é a culminância de um processo iniciado pelo menos desde 1995, e uma consequência imediata e natural do resultado do julgamento da ADPF 186, que questionava a constitucionalidade do sistema de cotas raciais adotado pela $\mathrm{UnB}^{8}$, ocorrida apenas 4 meses antes. A peça inicial da ação salientava que:

(...) na presente hipótese, sucessivos atos estatais oriundos da Universidade de Brasília atingiram preceitos fundamentais diversos, na medida em que estipularam a criação da reserva de vagas de $20 \%$ para negros no acesso às vagas universais e instituíram verdadeiro 'Tribunal Racial', composto por pessoas não-identificadas e por meio do qual os direitos dos indivíduos ficariam, sorrateiramente, à mercê da discricionariedade dos componentes, (...) (fl. 9) (MENDES, 2009).

E questionava, entre outras, se

a raça, isoladamente, pode ser considerada no Brasil um critério válido, legítimo, razoável, constitucional, de diferenciação entre o exercício de direitos dos cidadãos" (fl. 28). Defende o DEM 'que o acesso aos direitos fundamentais no Brasil não é negado aos negros, mas aos pobres e que o problema econômico está atrelado à questão racial. Alega que o sistema de cotas da UnB pode agravar o preconceito racial, uma vez que institui a consciência estatal da raça, promove ofensa arbitrária ao princípio da igualdade, gera discriminação reversa em relação aos brancos pobres, além de favorecer a classe média negra (fl. 29). Afirma que o item 7 e os subitens do Edital no 02/2009 do CES$\mathrm{PE} / \mathrm{UNB}^{9}$ violam o princípio da igualdade e da dignidade humana, na medida em que ressuscitam a crença de que é possível identificar a que raça pertence uma pessoa (fl. 29). Assim, indaga a respeito da constitucionalidade dos cri-

\footnotetext{
${ }^{8}$ A Arguição de Descumprimento de Preceito Fundamental (ADPF) 186 foi proposta pelo partido Democratas (DEM), em 2009. 0 relator foi o Min. Ricardo Lewandowski.

${ }^{9}$ Editais do vestibular da UnB.
} 
térios utilizados pela comissão designada pelo CESPE para definir a "raça" do candidato, afirmando que saber quem é ou não negro vai muito além do fenótipo. (...) A petição ressalta, ainda, que a aparência de uma pessoa diz muito pouco sobre a sua ancestralidade (fl. 30). Refere, com isso, que a "teoria compensatória", que visa à reparação do dano causado pela escravidão, não pode ser aplicada num país miscigenado como o Brasil. (MENDES, 2009, grifos dos autores).

Note-se que, no texto da ação, figuram alguns dos argumentos mais usados contra o sistema de cotas: as defesas das reservas de vagas deveriam ter um caráter social (pela renda) e não racial (atendendo aos indígenas e aos negros); o receio de uma nova discriminação reversa e uma política "racialista" por parte do Estado; a impossibilidade de políticas compensatórias ou de reparação "do dano causado pela escravidão".

O julgamento teve uma intensa exposição e extensa cobertura da mídia, além de redes sociais. Afinal, tratava-se de um momento decisório na trajetória das política de cotas nas universidades, no seu viés mais discutido, o "racial".

Na ocasião das deliberações finais, que encerrariam a longa polêmica legal sobre a política de cotas, além das partes arguentes e arguidas, tiveram a oportunidade de se expressar, como amici curiae, diversas entidades ligadas aos movimentos negro e indígena, como Educafro, Fundação Cultural Palmares, Movimento Negro Unificado, Movimento Pardo-Mestiço Brasileiro (MPMB), Fundação Nacional do Índio, Instituto de Advocacia Racial e Ambiental (IARA), Defensoria Pública da União, Movimento Contra o Desvirtuamento do Espírito da Política de Ações Afirmativas nas Universidades Federais e o Instituto de Direito Público e Defesa Comunitária Popular (IDEP). Além destas, foram ouvidos o representante do Conselho Federal da OAB, o Advogado Geral da União, o ministro Edson Santos de Souza, da SEPPIR ${ }^{10}$, o Co-

${ }^{10}$ Secretaria Especial de Políticas de Promoção de Igualdade Racial 
ordenador-Geral da Educação em Direitos Humanos da SEDH ${ }^{11}$, representante do MEC e da SESU, e o Diretor de Cooperação e Desenvolvimento o IPEA ${ }^{12}$. Outra questão levantada, talvez o aspecto mais criticado pelos alunos dos cursos preparatórios para o vestibular ${ }^{13}$ - a "relativização" do mérito acadêmico, foi a de um candidato não classificado nas 160 vagas de um vestibular da UFRGS, apesar de colocado em $132^{\circ}$ lugar.

No contraditório, foram retomadas e expostas praticamente todas as argumentações contra e a favor da política de cotas e, principalmente, sobre os aspectos operacionais da sua implantação. Contra as cotas, foi abordada a questão da não comprovação de renda por parte dos egressos de escolas públicas, nem de negros ${ }^{14}$; a inexistência de diferenciação biológica entre raças humanas ${ }^{15}$; o receio de se estabelecer um apartheid social nas universidades devido ao sistema de $\operatorname{cotas}^{16}$; o erro conceitual ao se considerar no mesmo grupo de "negros" os pardos, que são, ao lado de afrodescendentes, também índio e eurodescendentes $^{17}$; a qualidade do vestibular de ser uma forma de neutralizar a manifestação das discriminações, visto que alunos de qualquer raça, renda, sexo são avaliados apenas em função de seu desempenho ${ }^{18}$. Destaca-se a fala da advogada Roberta Kauffman, advogada do DEM, autora da ação: “A imposição de um modelo de

\footnotetext{
${ }^{11}$ Secretaria Especial de Direitos Humanos.

${ }^{12}$ Nas fls. 54-58 da ação, escreveu-se que "Sustenta-se, ademais, que os dados estatísticos referentes aos indicadores sociais são manipulados e que a pobreza no Brasil tem "todas as cores" (fls. 54-58). (MENDES, 2009).

${ }^{13}$ Ver Beraldo e Magrone, 2012.

${ }^{14}$ Wanda Marisa Gomes Siqueira, em nome de estudantes prejudicados no vestibular da UFRGS.

${ }^{15}$ Sérgio Danilo Pena, especialista em genética humana.

${ }^{16}$ Yvonne Maggie, em carta lida no tribunal.

${ }^{17}$ George de Cerqueira Leite Zarur, da Faculdade Latino-Americana de Ciências Sociais.

${ }^{18}$ Eunice Ribeiro Durham, também por carta lida no tribunal.
} 
estado racializado, por óbvio, traz consequências perversas para formação da identidade de uma nação. [...] Não existe racismo bom. Não existe racismo politicamente correto. Todo o racismo é perverso e precisa ser evitado." (G1, 2012). Também, a palavra de Juliana Ferreira Correa, representante do Movimento Pardo-mestiço, que aponta uma das contradições do racialismo: "Não podemos simplesmente considerar pardos e negros como iguais, ou que o pardo está inserido na categoria negra. Fazer tal afirmação é também racismo." (G1, 2012). Abordando o aspecto da reparação devida aos descendentes dos escravos, o representante da Associação de Procuradores do Estado - ANAPE, Ibsen Noronha "ressaltou, em síntese, que, com a instituição do sistema de cotas nas universidades, há um real perigo de se cometer injustiças tendo em conta uma suposta dívida histórica, pois, desde o século XVI, há registro de negros libertos no Brasil que prosperaram economicamente." (ADPF 186, 2012).

A favor da política de cotas, a lembrança de que, a partir do censo de 2010, negros já são majoritários na população, a redução das discriminações irá contribuir para consolidar a democracia brasileira, e que a comunidade universitária e científica se beneficia com a presença de $\operatorname{cotistas}^{19}$; as ações afirmativas ajustam aquelas condições que não foram dadas a determinados setores, para que todos possam concorrer em igualdade de condições, o acesso à educação universitária deve ser segundo a capacidade, mas o nosso vestibular não mede a capacidade, mede o investimento ${ }^{20}$; "o que se busca pela política de cotas para negros e indígenas não é para terem direito às migalhas, mas sim para terem acesso ao topo em todos os setores de responsabilidade e de comando na vida nacional em que esses dois segmentos não são devidamente representados, como manda a verdadeira

\footnotetext{
${ }^{19}$ Luiz Felipe de Alencastro, Fundação Palmares.

${ }^{20}$ Oscar Vilhena - CONECTAS
} 
democracia"21; a política de cotas raciais transcendem o âmbito universitário, pois também contribuem para a diversificação do mercado de trabalho ${ }^{22}$; "onde houver desigualdade, é obrigação e dever moral, ético e constitucional do Estado agir de modo próprio, ainda que de forma extraordinária e excepcional, para a equalização das oportunidades"23.

No dia seguinte (25/4) deu-se continuidade ao contraditório entre as partes, no que se refere à constitucionalidade ou não da política de cotas, com argumentação mais técnica, jurídica, focada em artigos e parágrafos da Constituição. A favor da constitucionalidade, falaram Fábio Konder Comparato e Flávia Piovesan, e contra Carlos Alberto Dias (2ª Vara Federal de Florianópolis-SC), José Roberto Ferreira Militão (OAB/SP - Comissão de Assuntos Antidiscriminatórios) e Helderli Feliz Castro, do Movimento Pardo-Mestiço Brasileiro (MPMB). Neste dia, também falaram Marcos Antonio Cardoso (CONEM), Sueli Carneiro (GELEDÉS), José Carlos Miranda (Movimento Negro Socialista), Alan Kardec Martins Barbiero (ANDIFES), Augusto Carnizella Chagas (UNE), João Feres Jr. (IUPERJ), Renato Hyuda de Luna Pedrosa (UNICAMP), Eduardo Magrone (UFJF) e Jânia Saldanha (UFSM).

Ao final, todos os 10 ministros votantes ${ }^{24}$ acompanharam a opinião do relator do processo, ministro Ricardo Lewandowski, que se pronunciou a favor da constitucionalidade da política adotada na UnB: "Qualquer critério adotado colocará candidatos em vantagem e desvantagem, porém é preciso observar o ganho para a sociedade como um todo (...) A política de reserva de vagas não é de nenhum modo estranha à Constituição." (citar). No entan-

\footnotetext{
${ }^{21}$ Kabengele Munanga - Centro de Estudos Africanos da USP.

${ }^{22}$ Leonardo Avritzer, UFMG.

${ }^{23}$ José Vicente - AFROBRÁS.

${ }^{24}$ O ministro Dias Tóffoli declarou-se impedido e não participou do julgamento, pois quando era advogado-geral da União, deu parecer favorável às cotas.
} 
to, precaveu-se as cotas precisam ter características "transitórias", com tempo de duração limitado. [Seja pelo] tempo necessário para que se alcance a isonomia e a justiça material, disse. Lewandowski diz que reconhece, na política de cotas da UnB, a característica de transitoriedade - já que o processo passa por uma revisão a cada dez anos - e que os métodos de seleção na instituição são "eficazes” (G1, 2012).

0 ministro Gilmar Mendes, que, apesar de acompanhar o voto do relator, fez críticas à política de cotas raciais validada pelo STF, lembra que se trata de uma iniciativa pioneira. Para ele, a reserva de vagas feita pela universidade deveria levar em conta também a condição econômica do candidato, sob pena de gerar distorções, como excluir um candidato branco e pobre do benefício. 0 ministro chegou a propor a revisão do modelo criado pela UnB, que, segundo ele, é "ainda constitucional", mas se for mantido como está poderá vir a ferir a Constituição:

Seria mais razoável adotar-se um critério objetivo de referência de índole socioeconômica. Todos podemos imaginar as distorções eventualmente involuntárias e eventuais de caráter voluntário a partir desse tribunal que opera com quase nenhuma transparência. Se conferiu a um grupo de iluminados esse poder que ninguém quer ter de dizer quem é branco e quem é negro em uma sociedade altamente miscigenada. $(\mathrm{G} 1,2012)$

Com a decisão final do STF, é afirmada a constitucionalidade da política de cotas e estabelecida a segurança jurídica para que as instituições federais de ensino superior pudessem avançar em seus projetos de inclusão.

Movimentos negros, contra a discriminação racial e por uma posição igualitária na sociedade existem pelo menos desde o começo do século XX, com momentos variados em termos de representatividade e influência na sociedade. No que tange a este trabalho, as ideias acerca de políticas afirmativas, voltadas para 
negros, e as entidades vinculadas a estas aspirações, começam a surgir e exercer alguma pressão social durante os anos 1970, quando a ditadura militar vive o seu momento mais forte:

No início da década de 1970, é possível registrar a formação de entidades que, como diz o relatório do $\mathrm{SNI}^{25}$, buscavam denunciar o racismo e organizar a comunidade negra. Por exemplo, o Grupo Palmares, criado em Porto Alegre em 1971; o Centro de Estudos e Arte Negra (Cecan), aberto em São Paulo em 1972; a Sociedade de Intercâmbio Brasil-África (Sinba), inaugurada no Rio de Janeiro em 1974, e o Bloco Afro Ilê Aiyê, fundado em Salvador também em 1974. (ALBERTI e PEREIRA, 2008).

A partir de 1973, com os choques do petróleo ensejando o fim do "milagre econômico", a economia do país - e a própria ditadura - começam a declinar.

No final da década de 70 a inflação chega a $94,7 \%$ ao ano. Em 1980 bate em 110\% e, em 1983, em 200\%. Nesse ano, a dívida externa ultrapassa os US\$ 90 bilhões e $90 \%$ da receita das exportações é utilizada para o pagamento dos juros da dívida. 0 Brasil mergulha em nova recessão e sua principal consequência é o desemprego. Em agosto de 1981 há 900 mil desempregados nas regiões metropolitanas do país e a situação se agrava nos anos seguintes ${ }^{26}$.

Em julho de 1978, nasce em São Paulo o Movimento Negro Unificado Contra a Discriminação Racial (MNU), em um ato público organizado para protestar contra o assassinato de Robson Silveira da $\mathrm{Luz}^{27}$, e a discriminação sofrida por quatro jovens ne-

\footnotetext{
${ }^{25}$ Os autores citam um relatório do Serviço Nacional de Informações sobre os movimentos negros.

26 Ver Portal São Francisco, acessível em http://www.portalsaofrancisco.com.br/alfa/ ditadura-militar/economia-na-ditadura-militar.php.

${ }^{27}$ Morto no distrito policial de Guaianazes, para onde tinha sido levado preso, acusado de roubar frutas numa feira.
} 
gros, impedidos de treinar vôlei no Clube de Regatas Tietê2 ${ }^{28}$. A promulgação da Lei da Anistia, em agosto de 1979, embora não tivesse sido tão ampla e irrestrita como queriam as entidades congregadas no Comitê Brasileiro da Anistia, mostra a força das pressões feitas por estudantes, jornalistas, artistas e políticos de oposição, no Brasil e no exterior ${ }^{29}$. A perspectiva do fim do período ditatorial inspira a ampliação de movimentos que trazem outras palavras para o cotidiano nacional, como "direitos humanos", "cidadania”, "bem-estar da sociedade”, que irão reger, em grande parte, os princípios da Constituição de $1988^{30}$.

É neste momento, de abertura política, e "abertura das cabeças", que surgem novas interpretações sobre as relações raciais no País:

${ }^{28}$ Um relato do SNI descreve o evento: "Realizou-se em São Paulo, no dia 7 julho de 1978, na área (...) Teatro Municipal, junto ao Viaduto do Chá, uma concentração organizada pelo autodenominado "Movimento Unificado Contra a Discriminação Racial”, integrado por vários grupos, cujos objetivos principais anunciados são: denunciar, permanentemente, todo tipo de racismo e organizar a comunidade negra. Embora não seja, ainda, um "movimento de massa", os dados disponíveis caracterizam a existência de uma campanha para estimular antagonismos raciais no País e que, paralelamente, revela tendências ideológicas de esquerda. Convém assinalar que a presença no Brasil de Abdias do Nascimento, professor em Nova Iorque, conhecido racista negro, ligado aos movimentos de libertação na África, contribuiu, por certo, para a instalação do já citado "Movimento Unificado" (ALBERTI e PEREIRA, 2008)

${ }^{29}$ O presidente gen. Ernesto Geisel (1907-96) iniciou o movimento de abertura política em seu mandato (1974-79) enfrentando a "linha dura" das Forças Armadas, e foi seguido pelo gen. Figueiredo (1918-1999), que, em sua posse prometeu que faria "deste país uma democracia", e, em uma entrevista, ameaçou "prender e arrebentar" quem fosse contra a abertura. 0 presidente dos EUA era Jimmy Carter (1924-), prêmio Nobel da Paz, (1977-1981).

${ }^{30}$ Esta transição não foi feita sem que os últimos espasmos de reação da "linha dura" - o que foi chamado de "terrorismo de Estado", como no atentado de abril de 1981, numa comemoração do Dia do Trabalho, durante um show no Riocentro, quando dois militares sofreram um acidente quando explodiu a bomba que planejavam lançar no auditório. Um militar morreu na hora e o sobrevivente, gravemente ferido, não esclarece o que aconteceu. 
A redemocratização da sociedade brasileira inaugurada no final dos anos 1970 coincide, no plano das ciências sociais, com a divulgação de novas interpretações sobre as relações raciais no Brasil. Até então, os estudos patrocinados pela Unesco no início da década de 1950 e seus desdobramentos nos anos 1960 haviam revelado as tensões entre o mito da democracia racial e o "racismo à brasileira". 0 inventário realizado pelo chamado projeto Unesco sobre o preconceito e a discriminação racial caminhou pari passu com a reiteração da diferença com relação à experiência norte-americana. 0 ciclo de pesquisas da Unesco tornou-se um marco, entre os cientistas sociais, na caracterização da questão racial no Brasil. (...) A partir do final da década de 1970, pesquisadores como Carlos Hasenbalg e Nelson do Valle e Silva, com base em dados quantitativos e apoiados em uma visão crítica da teoria da modernização e de determinadas análises estruturalistas, contestaram interpretações oriundas do Projeto Unesco, a exemplo de Florestan Fernandes, quanto à natureza do "racismo à brasileira" e à subsunção da categoria raça à classe. Uma das críticas ao sociólogo paulista deve-se à interpretação do preconceito racial como um resquício da herança escravocrata e, como tal, tendente a desaparecer com o surgimento de uma sociedade capitalista, democrática, aberta e competitiva (MAIO e SANTOS, 2006, p.15-16).

\section{No final da década de 1970, o movimento negro contemporâneo se forma e se consolida:}

A partir de uma "constelação de associações religiosas, culturais, políticas, filantrópicas com graus de articulação muito variados entre si, ao longo dos anos 1970, quer sob a influência político-cultural norte-americana, especialmente do movimento dos direitos civis, quer sob a ascendência dos intelectuais marxistas africanos das lutas anticoloniais de libertação nacional contra o império português ${ }^{31}$ que criticaram a visão integracionista das lideranças brasileiras entre os anos 1930 e 1960. A virada político-ideológica é comumente atribuída à criação do Movimento Negro Unifi-

${ }^{31}$ Ficaram independentes de Portugal: Cabo Verde, São Tomé e Príncipe, Angola e Moçambique, todas em 1975. 
cado contra a Discriminação Racial, em 1978. (MAIO e SANTOS, 2006, p.16)

0 zeitgeist dos anos 1970 e 1980 compreendia um forte movimento cultural e, principalmente, musical, de temática ou influência negra. Na música popular, há uma espécie de redescoberta e revalorização do samba, com as gravações dos primeiros discos de Cartola ${ }^{32}$ (1974) e Nelson Cavaquinho ${ }^{33}$ (1970), e a fértil produção de Paulinho da Viola ${ }^{34}$, com 10 discos gravados entre 1970 e 1980. Também nas escolas de samba, os temas dos desfiles são majoritariamente negros. Citando alguns: "Festa para um Rei Negro" (SALGUEIRO, 1971), "Pixinguinha” (PORTELA, 1973), "Macunaíma” (PORTELA, 1975), "A criação do mundo na tradição nagô" (BEIJA-FLOR, 1978), “Oxumaré, a lenda do arco-íris" (Imperatriz Leopoldinense, 1979). Um trabalho prolífico e afirmativo é o do compositor e escritor Martinho da Vila (1938 - ), que tem um ápice em 1988, com Kizomba: a festa da raça, que ajudou no campeonato para a GRES Unidos de Vila Isabel.

Outro aspecto do "ponto de virada" nos anos 1970 é ressaltado pelo professor Joel Rufino dos Santos:

Eu diria que a transformação no seio do movimento negro brasileiro recebe influência direta de dois elementos importantíssimos: o black soul dos Estados Unidos e as lutas de libertação da África. Torna-se importante conhecer a história da África e da luta contra a escravidão. Depois de décadas de primazia da ideia de democracia racial, ganha força a percepção de que há uma grave situação a ser enfrentada. (LUNA, 2013, p.15)

\footnotetext{
${ }^{32}$ Angenor de Oliveira, o Cartola, (1908-1980).

${ }^{33}$ Nelson Antônio da Silva, Nelson Cavaquinho, (1911-1986).

${ }^{34}$ Paulo César Batista de Faria, Paulinho da Viola (1942- ).
} 
O black soul citado pelo professor Santos é, basicamente, a voz e o ritmo que seria grande parte da trilha sonora deste tempo: a soul music e ofunk, na voz de James Brown ${ }^{35}$ :

Ao lançar o funk em 1967, James Brown jamais imaginou que fosse influenciar a juventude negra brasileira. Na periferia carioca o seu som embalou o movimento da cultura negra na década de 80 . No Rio de Janeiro, os primeiros bailes funk aconteceram nas quadras de escolas de samba, como a Portela e o Império Serrano, e em clubes como os Magnatas, Astória FC e Renascença (...) que era ponto de encontro de artistas negros engajados politicamente, como Antonio Pompeu e Zezé Mota. 0 local também era frequentado por Asfilófilo Filho, o Dom Filó, um engenheiro negro que promovia a exibição de filmes sobre jazz nos morros do Macaco, Vila Isabel e Salgueiro e a execução de sucessos de James Brown na rádio Tamoio. 0 ritmo contagiante terminou sendo incorporado e recriado por cantores e compositores negros como Genival Cassiano, Toni Tornado ${ }^{36}$ e o inesquecível Tim Maia ${ }^{37}$. (ALBUQUERQUE e FRAGA FILHO, 2006, p.282).

Em julho de 1976, a repórter Lena Frias publicou no Jornal do Brasil uma matéria com o título Black Rio - O Orgulho (importado) de ser Negro no Brasil. 0 texto descortinava um movimento até então ignorado, mesmo para os cariocas, "movimento Black Rio":

${ }^{35}$ James Joseph Brown Jr., James Brown (1933-2006), cantor, dançarino, compositor e produtor musical norte-americano.

${ }^{36}$ Antônio Viana Gomes, Tony Tornado ou Toni Tornado (1930-). Em 1970 chocou quem assistia o V Festival Internacional da Canção, ao interpretar a "canção soul nos moldes de James Brown", BR-3 (de Antonio Adolfo e Tibério Gaspar), que venceu o festival.

${ }^{37}$ Sebastião Rodrigues Maia (1942-1998), o Tim Maia, o cantor mais bem sucedido do grupo, responsável pela introdução do estilo soul na música popular brasileira. Entre 1959 e 1964, morou nos Estados Unidos, onde teve seus primeiros contatos com o soul, vindo a ser preso e deportado por roubo e porte de drogas. Tim Maia gravou seu primeiro disco em 1970, repleto de referências e no estilo da black music, que manteve até morrer. 
Uma cidade de cultura própria desenvolve-se dentro do Rio. Uma cidade que cresce e assume características muito específicas. Cidade que o Rio, de modo geral, desconhece ou ignora. Ou porque o Rio só sabe reconhecer os uniformes e os clichês, as gírias e os modismos da Zona Sul; ou porque prefere ignorar ou minimizar essa cidade absolutamente singular e destacada, classificando-a no arquivo descompromissado do modismo; ou porque considera mais prudente ignorá-la na sua inquietante realidade. Uma cidade cujos habitantes intitulam a si mesmos de "blacks" ou "browns"; cujo hino é uma canção de James Brown ou uma música dos Blackbyrds, cuja bíblia é Wattstax ${ }^{38}$, a contrapartida negra de Woodstock (...) cujo modelo é o negro americano, cujos gestos copiam, embora sobre a cópia já se criem originalidades. (PINHEIRO, 2013)

\section{A Constituição de $1988^{39}$ incorporou duas reivindicações do movimento: a criminalização do racismo (Artigo 5) e o reco- nhecimento da propriedade das terras de remanescentes de quilombos (Artigo 68 do Ato das Disposições Constitucionais Transitórias).}

Na verdade, durante todos os anos 80 e na primeira metade dos anos 90 que antecederam a posse de [Fernado Henrique] Cardoso, as mobilizações em torno do centenário da Abolição da Escravatura e dos 300 anos de Zumbi possibilitaram que o diagnóstico sobre as desigualdades raciais brasileiras, assim como o racismo à brasileira, fosse amplamente discutido na imprensa (Guimarães, 1998). Especialmente porque, a partir da regulamentação das disposições transitórias da Constituição de 1988, que tornou crime a prática a prática de preconceitos de raça, passou a haver uma

\footnotetext{
38 Concerto de música negra, realizado no Los Angeles Memorial Coliseum, em 20/08/1972, organizado pela Stax Records, em comemoração dos 17 anos dos motins em Watts (distúrbios civis no distrito de mesmo nome, em Los Angeles, California, que duraram de 11 até 15 de Agosto de 1965). Há um excelente documentário sobre o festival em https://www.youtube.com/watch?v=dwuAwSbxbNk.

${ }^{39}$ Aos 100 anos da Abolição, o que motivou uma série de ações de protesto que denunciavam as condições de vida dos negros no país,
} 
grande movimentação das ONGs negras em torno da denúncia e da perseguição legal contra atos de discriminação. Foi justamente o esgotamento da estratégia de combater as desigualdades punindo a discriminação racial que levou as entidades negras a demandar políticas de ação afirmativa. (GUIMARÃES, 2003, p.253)

Quanto à inserção de negros na educação, em um contexto generalizado de perda de qualidade em todos os níveis de ensino na década de 1980, é ressaltado a seguir:

As informações da PNAD de 1982 indicaram que, no que diz respeito ao acesso ao sistema escolar, uma proporção mais elevada de crianças não-brancas ingressa tardiamente na escola. Além disso, a proporção de pretos e pardos que não tem acesso de todo à escola é três vezes mais do que o dos brancos. Esta desigualdades não podem ser explicadas nem por fatores regionais nem pelas circunstâncias socioeconômicas das famílias. Embora uma melhor situação socioeconômica reduza a proporção de crianças que não tem acesso à escola independentemente de sua cor, ainda persiste uma diferença clara nos níveis gerais de acesso entre crianças brancas e não-brancas mesmo nos níveis mais elevados de renda familiar per capita. (HASENBALG e SILVA, 1990, p.12, grifos dos autores).

Em 1995, na homenagem dos 300 anos de Zumbi dos Palmares, o governo FHC institui um Grupo de Trabalho Interministerial para a valorização da População Negra, parte do Programa Nacional dos Direitos Humanos. A questão dos direitos dos negros entra, por assim dizer, na agenda do governo federal que abriga no ano seguinte o seminário internacional Multiculturalismo e Racismo: o Papel da "Ação Afirmativa" nos Estados Democráticos Contemporâneos, uma promoção do Ministério da Justiça com apoio do Itamaraty. Talvez tenha sido a primeira vez que a tradução de affirmative actions tenha aparecido em um locus oficial. A reunião foi chancelada por um governo que reconhecia oficialmente a existência do racismo no Brasil. (MAIO e SANTOS, 


\section{6, p.18). Um governo cujo presidente é um sociólogo afeito às questões raciais ${ }^{40}$, ou seja, um momento que parece contar com as condições adequadas e as personagens certas.}

\section{No entanto, na própria abertura dos trabalhos, o presidente mostra uma certa}

ambivalência ao tratar dos temas das relações raciais e das ações afirmativas. Convocando os participantes a exercerem a imaginação social diante do dilema racial brasileiro e alertando para o perigo do mimetismo, clara referência ao modelo norte-americano (...) condenou a hipocrisia em face da intolerância racial no Brasil, mas, ao mesmo tempo, valorizou a ambiguidade que faria parte da formação cultural brasileira. (MAIO e SANTOS, 2006, p.19).

\section{Esta ambivalência, a par do reconhecimento da existência de discriminação racial no país, diz muito sobre a lenta no mito das relações raciais no país.}

Às vezes chamado de mito da democracia racial, essa narrativa foi desenvolvida por intelectuais brasileiros no século XX, como Gilberto Freyre e outros, além de alguns estrangeiros. Isso funcionou bem contra várias teorias racistas e foi adotado pelo Estado como o centro de uma discussão sobre a identidade nacional e integração social. Contudo, com o retorno do Brasil à democracia liberal na década de 1980, esse mito foi se tornando um obstáculo em vez de suporte à expansão dos direitos e oportunidades civis, políticas e sociais. (FERES JÚNIOR, DAFLON e CAMPOS, 2012, p.411).

\footnotetext{
40 "O presidente Fernando Henrique Cardoso, sociólogo que fez parte, junto com Otávio Ianni, da segunda geração do projeto UNESCO, havia auxiliado Florestan Fernandes e Roger Bastide na pesquisa sobre as relações entre brancos e negros na cidade de São Paulo nos anos 1950. No início da década de 1960, Cardoso concluiu sua tese de doutorado, sob orientação de Florestan, sobre as relações entre capitalismo e escravidão no Rio Grande do Sul." (STEIL, 2006)
} 
Embora uma série de propostas de valorização das condições de vida dos negros ter sido incluída no PNDH, pouca coisa saiu do papel até 2001, embora tenham se multiplicadas os projetos de instituições privadas e programas de governos locais progressistas de combate à discriminação racial, apesar da resistência do governo federal em implementar políticas de grande escala para o combate das desigualdades raciais e a discriminação (TELLES, 2003, p.80).

O próximo grande passo foi a participação brasileira na Terceira Conferência Mundial contra o Racismo, Discriminação Racial, Xenofobia e Outras formas de intolerância, promovida pela ONU e realizada entre agosto e setembro de 2001, na cidade de Durban, África do Sul. E, tanto quanto esta participação, os debates, eventos e relatórios que antecederam a conferência projetaram na mídia, com grande intensidade, os aspectos da "causa dos negros". Por exemplo, algo que causou certo constrangimento foi a escolha do Chile como país-sede de uma das conferências regionais preparatórias para Durban. Pelo seu grande contingente de negros, por sua cultura e por sua história, o Brasil seria, naturalmente, o país escolhido. No entanto, o representante da Fundação Palmares - então, o principal interlocutor do governo com os movimentos negros - anunciou que o Brasil não seria o anfitrião, alegando que os líderes negros não queriam que a conferência fosse no Brasil (TELLES, 2003, p.87), além dos costumeiros motivos financeiros. A razão real parecia ser a preocupação do governo com o rápido desmoronamento da imagem internacional de tolerância racial do Brasil e com o fato de que tal conferência chamaria atenção para as reivindicações do movimento negro. (TELLES, 2003, p.88)

Mesmo que a conferência tenha derivado em conflitos entre os blocos EUA-Israel e países árabes, sobre questões do sionismo como uma forma de racismo, e a polêmica entre países europeus e africanos acerca do que seriam políticas compensatórias e de reparação do colonialismo e escravidão, os resultados foram po- 
sitivos e relevantes para o movimento negro: o Brasil foi signatário do documento final que recomendava a adoção de políticas baseadas em ações afirmativas.

A partir da conferência de Durban, como se fosse um sinal para avançar nas políticas de inclusão, as mudanças se sucederam numa escala crescente, embora ainda sem uma legislação federal explícita sobre a implementação de ações afirmativas - as iniciativas eram estaduais ou criadas em processos internos $^{41}$. Ainda em 2001, no final do ano, a Assembleia Legislativa do Estado do Rio de Janeiro estabelece uma percentagem das vagas das universidades estaduais para pretos e pardos. A UERJ e a UENF, no Rio de Janeiro, e a UNEB.

Pouco tempo depois, a UnB torna-se a primeira IFES a fazer a reserva de $20 \%$ das vagas para negros, em 2004. Outras universidades se sucedem na implantação do sistema de cotas, até 2012. Entre elas, a UFJF.

\section{Resultados na U niversidade Federal de Juiz de Fora - U FJF}

A UFJF instituiu a política de cotas em 2004-5, e o primeiro concurso vestibular sob o novo sistema ocorreu em 2006. No sistema da UFJF, a metade das vagas de cada curso é reservada para alunos de escolas públicas, e desta parte, $25 \%$ são destinadas a candidatos autodeclarados negros, isto é, pretos e pardos. Os candidatos não cotistas são chamados grupo $\mathrm{C}$, os candidatos vindos de escolas públicas são denominados grupo $\mathrm{B}$, e os negros, grupo A. 0 número de ingressos, por ano e tipo de cotas, é o seguinte:

\footnotetext{
41 "Durante a administração Lula, a maioria dos programas (77\%) foram instituídos por decisões internas às universidades, geralmente por seus conselhos universitários, enquanto às demais decisões (23\%) foram resultados de leis estaduais." (FERES JÚNIOR, DAFLON e CAMPOS, 2012).
} 
Antonio Fernando de C. A. Beraldo; Eduardo Magrone; Tailiny Paula Ventura

Tabela 4 - Ingressantes na UFJF, por tipo de cotas, 2006-2012

\begin{tabular}{l|r|r|r|r|r|r|r|r}
\hline \multirow{2}{*}{ Tipo de Cotistas } & \multicolumn{6}{|c|}{ Ano de Ingresso } & \multirow{2}{*}{ Total } \\
\cline { 2 - 7 } & $\mathbf{2 0 0 6}$ & $\mathbf{2 0 0 7}$ & $\mathbf{2 0 0 8}$ & $\mathbf{2 0 0 9}$ & $\mathbf{2 0 1 0}$ & $\mathbf{2 0 1 1}$ & $\mathbf{2 0 1 2}$ & \\
\hline Não Cotistas C & 1.419 & 1.312 & 1.235 & 1.238 & 1.420 & 1.687 & 1.366 & 9.677 \\
Cotistas B & 285 & 356 & 496 & 796 & 993 & 1.150 & 930 & 5.006 \\
Cotistas A & 83 & 88 & 157 & 202 & 282 & 334 & 295 & 1.441 \\
Total & 1.787 & 1.756 & 1.888 & 2.236 & 2.695 & 3.171 & 2.591 & 16.124 \\
Percentual de Cotistas & 20,6 & 25,3 & 34,6 & 44,6 & 47,3 & 46,8 & 47,3 & 40,0 \\
\hline
\end{tabular}

Fonte: Dados do $\mathrm{CGCO}^{42}$, processados pelos autores.

Nota: Não inclui os ingressantes no campus de Governador Valadares, 315 ingressantes,

Pode-se notar que o percentual de alunos cotistas cresceu de 20,6 em 2006 para 47,3 em 2012. No total acumulado entre 2006-2012, cerca de 40\% são cotistas, e a tendência é que a partir de 2015 as cifras se estabilizem de acordo com a Lei das Cotas. Notar também que o número de ingressantes sobe de 1,8 mil para 2,6 mil, um aumento de $45 \%$. Este aumento é devido às mudanças em alguns cursos e à criação de novos cursos e, principalmente, dos Bacharelados Interdisciplinares (BIs) que, entre 2009 e 2012, acrescentaram 1.800 vagas nos vestibulares. Dos ingressantes neste período, a situação acadêmica atual (março de 2014) é a seguinte:

Tabela 5 - Situação acadêmica atual dos Ingressantes 2006-2012

\begin{tabular}{l|r|r|r|r}
\hline & \multicolumn{3}{|c|}{ Situação Acadêmica } & \multirow{2}{*}{ Total } \\
\cline { 2 - 4 } & Ativo & Concluído & Não ativo & \\
\hline Não Cotistas C & 5112 & 2929 & 1634 & 9675 \\
Percentual & 52,8 & 30,3 & 16,9 & 100,0 \\
Cotistas B & 3383 & 941 & 682 & 5006 \\
Percentual & 67,6 & 18,8 & 13,6 & 100,0 \\
Cotistas A & 1017 & 216 & 208 & 1441 \\
Percentual & 70,6 & 15,0 & 14,4 & 100,0 \\
Total & 9512 & 4086 & 2524 & 16122 \\
Percentual & 59,0 & 25,3 & 15,7 & 100,0 \\
\hline
\end{tabular}

Fonte: Dados do CGCO, processados pelos autores.

Nota: 1 - Não ativo: Abandono, desistências, cancelamentos e trancamentos.

Os cursos com maior percentual de não-cotistas são: cursos an-

${ }^{42}$ CGCO- Centro de Gestão do Conhecimento Organizacional. 
tigos, Educação Artística (84\% C e 4\% A), e Física (73,4\% C e 6,3\% A); cursos novos, Estatística (84\% C e 4\% A). Os cursos com menos cotistas A são Matemática (3,1\%) e Turismo (3,3\% D e $3,8 \% \mathrm{~N}$ ). Nenhum curso tem mais de $11 \%$ de cotistas A. 0 que mais se aproxima é o curso de Direito, Noturno, com 10,6\%.

Dos 16 mil ingressantes no período, cerca de $25 \%$ já concluíram o curso, e desses, cerca de $72 \%$ são não-cotistas. Os não ativos são $16 \%$, dos quais $64 \%$ são não-cotistas. A evasão é menor entre os cotistas $B, 13,6 \%$ dos ingressantes nesta faixa, seguida de perto dos cotistas A, com 14,4\% dos ingressantes neste grupo. Os cursos com maior taxa de evasão no período foram Matemática (64\%), Física (58\%) e Ciências Sociais (56\%). As menores taxas de evasão foram as dos cursos de Medicina (2,2\%), Odontologia (5,1\%), Direito Diurno (5,2\%) e Noturno (6,1\%), Arquitetura (7,5\%), e Farmácia, Psicologia e Comunicação (todos com cerca de 8\%).

Quanto ao rendimento acadêmico, utilizamos para comparação entre os três grupos as variáveis IRA ${ }^{43}$, Percentual de Reprovações por Nota e Percentual de Reprovações por Infrequência. Os resultados foram os seguintes:

IRA: As estatísticas são as seguintes:

Tabela 6 - Estatísticas do IRA

\begin{tabular}{l|r|r|r|r|r}
\hline IRA & Média & Desvio-Padrão & CV $^{\mathbf{1}}$ & Mediana & AIQ $^{\mathbf{2}}$ \\
\hline Não Cotistas C & 72,0 & 17,5 & 0,244 & 77,4 & 16,8 \\
Cotistas B & 70,6 & 17,2 & 0,244 & 75,7 & 17,7 \\
Cotistas A & 65,0 & 19,5 & 0,300 & 70,7 & 22,0 \\
\hline
\end{tabular}

Fonte: Base de dados dos ingressantes 2006-2012, processados pelos autores.

${ }^{43}$ IRA- Índice de Rendimento Acadêmico, é a média ponderada das notas finais dos alunos nas disciplinas cursadas. A ponderação é feita pelo número de créditos das disciplinas:

$$
\operatorname{IRA}=\frac{\sum_{1}^{k} c r_{i} n f_{i}}{\sum_{1}^{k} c r_{i}}
$$


Nota: 1 - CV: coeficiente de variação; 2 - AIQ: amplitude interquartílica.

Pelos dados da tabela anterior, pode-se perceber que as estatísticas de tendência central (média e mediana) mostram uma ordenação cotistas $\mathrm{C}>$ cotistas $\mathrm{B}>\operatorname{cotistas} \mathrm{A}$. As medidas de dispersão (desvio-padrão, CV e AIQ) mostram também uma homogeneidade maior entre os valores do IRA do grupo de não-cotistas $\mathrm{C}$, seguido dos cotistas B e A.

Foram utilizados os testes estatísticos não paramétricos de Kruskall-Wallis e Mann-Whitney, para testar a hipótese de igualdades entre os grupos. Foi utilizado o pacote estatístico SPSS (Statistical Package for Social Sciences). Os resultados foram os seguintes:

Quadro 1

\begin{tabular}{|l|l|l|l|}
\hline Grupo 1 & Grupo 2 & $\begin{array}{l}\text { p-value } \\
\text { (significância) }\end{array}$ & Resultado \\
\hline C (não-cotistas) & $\begin{array}{l}\text { B (cotistas } \\
\text { - escola } \\
\text { pública) }\end{array}$ & 0,000 & $\begin{array}{l}\text { Há diferença estatística signifi- } \\
\text { cativa entre os grupos, o IRA dos } \\
\text { não-cotistas é maior do que o } \\
\text { dos cotistas B }\end{array}$ \\
\hline $\begin{array}{l}\text { B (cotistas - escola } \\
\text { pública) }\end{array}$ & $\begin{array}{l}\text { A (cotistas } \\
\text { negros) }\end{array}$ & 0,000 & $\begin{array}{l}\text { Há diferença estatística signifi- } \\
\text { cativa entre os grupos, o IRA dos } \\
\text { cotistas B é maior do que o dos } \\
\text { cotistas A }\end{array}$ \\
\hline
\end{tabular}

O quadro anterior confirma que há diferença estatística significativa nos valores da variável IRA, entre os grupos de cotistas $C$, B e A, que se posicionam nesta ordem.

Percentual de Reprovações por Nota - As estatísticas são as seguintes:

Tabela 7 - Percentual de Reprovações por Nota

\begin{tabular}{l|r|r|r|r|r}
\hline Reprovações por Nota (\%) & Média & Desvio-Padrão & CV & Mediana & AIQ \\
\hline Não Cotistas C & 14,1 & 14,1 & 1,000 & 8,9 & 16,4 \\
Cotistas B & 15,5 & 14,9 & 0,958 & 10,2 & 18,5 \\
Cotistas A & 19,1 & 16,7 & 0,874 & 13,9 & 21,9 \\
\hline
\end{tabular}

Fonte: Base de dados dos ingressantes 2006-2012, processados pelos autores.

Nota: 1 - CV: coeficiente de variação; 2 - AIQ: amplitude interquartílica. 
Os testes de hipóteses de igualdade dos grupos (Kruskal-Wallis e Mann-Whitney) mostram os seguintes resultados:

\section{Quadro 2}

\begin{tabular}{|l|l|l|l|}
\hline Grupo 1 & Grupo 2 & $\begin{array}{l}\text { p-value } \\
\text { (significância) }\end{array}$ & Resultado \\
\hline C (não-cotistas) & $\begin{array}{l}\text { B (cotistas - } \\
\text { escola pública) }\end{array}$ & 0,000 & $\begin{array}{l}\text { Há diferença estatística significa- } \\
\text { tiva entre os grupos, o percentual } \\
\text { de reprovações por nota dos não- } \\
\text {-cotistas é menor do que o dos co- } \\
\text { tistas B }\end{array}$ \\
\hline $\begin{array}{l}\text { B (cotistas - es- } \\
\text { cola pública) }\end{array}$ & $\begin{array}{l}\text { A (cotistas } \\
\text { negros) }\end{array}$ & 0,000 & $\begin{array}{l}\text { Há diferença estatística significati- } \\
\text { va entre os grupos, o percentual de } \\
\text { reprovação por nota dos cotistas B } \\
\text { é menor do que o dos cotistas A }\end{array}$ \\
\hline
\end{tabular}

Os resultados dos testes mostram que há diferença estatística significativa entre os grupos de cotistas para esta variável, e que os não-cotistas $\mathrm{C}$ apresentam os menores percentuais de reprovação por nota, seguidos dos cotistas B e, na pior situação, os cotistas A.

A variável Reprovação por infrequência apresenta as seguintes estatísticas:

Tabela 8 - Estatísticas de Reprovação por Infrequência

\begin{tabular}{l|r|r|r|r|r}
\hline Reprovação por Infrequência & Média & Desvio-Padrão & CV & Mediana & AIQ \\
\hline Não Cotistas C & 12,0 & 14,9 & 1,240 & 5,9 & 12,5 \\
Cotistas B & 11,3 & 13,5 & 1,198 & 6,1 & 11,4 \\
Cotistas A & 12,8 & 13,8 & 1,077 & 7,8 & 13,1 \\
\hline
\end{tabular}

Fonte: Base de dados dos ingressantes 2006-2012, processados pelos autores.

Nota: 1 - CV: coeficiente de variação; 2 - AIQ: amplitude interquartílica.

Os testes de hipóteses de igualdade dos grupos (Kruskal-Wallis e Mann-Whitney) mostram os seguintes resultados: 


\section{Quadro 3}

\begin{tabular}{|l|l|l|l|}
\hline Grupo 1 & Grupo 2 & $\begin{array}{l}\text { p-value } \\
\text { (significância) }\end{array}$ & Resultado \\
\hline $\begin{array}{l}\text { C (não- } \\
\text { cotistas) }\end{array}$ & $\begin{array}{l}\text { B (cotistas } \\
\text { - escola } \\
\text { pública) }\end{array}$ & 0,548 & $\begin{array}{l}\text { Não há diferença estatística significativa en- } \\
\text { tre os grupos, o percentual de reprovações } \\
\text { por infrequência dos não-cotistas é igual, } \\
\text { em termos estatísticos, ao dos cotistas B }\end{array}$ \\
\hline $\begin{array}{l}\text { B (cotistas } \\
\text { - escola } \\
\text { pública) }\end{array}$ & $\begin{array}{l}\text { A (cotistas } \\
\text { negros) }\end{array}$ & 0,000 & $\begin{array}{l}\text { Há diferença estatística significativa entre } \\
\text { os grupos, o percentual de reprovação por } \\
\text { infrequência dos cotistas B é menor do que } \\
\text { o dos cotistas A }\end{array}$ \\
\hline
\end{tabular}

\section{Outros fatores:}

\section{Alunos egressos de escolas de alto rendimento: A cidade de Juiz de Fora, e seu entorno, conta com excelentes escolas públi- cas de ensino médio, e isto se reflete nos vestibulares e no rendi- mento acadêmico dos cotistas:}

No período 2006-2011, cerca de $26 \%$ dos cotistas B e $23 \%$ dos cotistas A ingressantes na UFJF são oriundos de escolas públicas federais, que, tradicionalmente, são muito bem avaliadas pelo IDEB e outras metodologias de avaliação. São os colégios federais de aplicação, e os colégios militares, da PMMG. Este tipo de aluno, que com raras exceções, é muito melhor preparado do que os das escolas públicas municipais e estaduais - e muitas particulares causa uma distorção quando se avalia a eficiência da política de cotas. São ex-alunos de escolas como o CEFET/CTU, Colégios de Aplicação João XXIII (UFJF) e Coluni (UFV), e mesmo o Colégio Militar, que aprovaram 1.280 candidatos, cerca de $24 \%$ das vagas para cotistas $^{44}$. (BERALDO e MA-

${ }^{44} \mathrm{O}$ CEFET de Juiz de Fora é o antigo Colégio Técnico Universitário, até 2008 ligado à UFJF - é a 6⿳a melhor classificada em MG; o João XXIII é o colégio de aplicação da UFJF; o Coluni é o colégio de aplicação da UFV (Universidade Federal de Viçosa, MG), a escola pública melhor classificada pelo ENEM no Brasil (2010 e anteriores) - no seu "vestibulinho", a taxa é de 11 candidatos por vaga; o colégio Tiradentes, da PMMG, é a 5 no estado (ENEM), e possui também um "vestibulinho" como sistema de ingresso. Das 10 
GRONE, 2012, p.378).

Pela condição destes alunos ingressarem como cotistas B e A, muitas vezes suas boas colocações no vestibular e suas excelentes performances acadêmicas induzem a uma conclusão equivocada, em que se afirma que equivalem em preparo aos não cotistas (grupo C). Isto não é verdade, estes não são cotistas "típicos", e, para eles, não era necessário a reserva de vagas nem as mudanças no vestibular. Na base de dados 2006-2012 encontramos indicativo de uma correlação forte entre o percentual, nos cursos, de alunos egressos destas escolas e as melhores pontuações no IRA.

\section{Cursinhos preparatórios ao Vestibular}

Praticamente $85 \%$ dos alunos cotistas frequentaram cursinhos preparatórios, o que mascara o caráter de "escola pública" em que se enquadraram. Em cursos de maior relação candidato-vaga, como Medicina, Direito ou Engenharia, é quase impossível ingressar na universidade sem ter frequentado o cursinho, mesmo tendo cursado escolas particulares ou públicas de alto rendimento. Em levantamentos feitos nestes cursos, encontraram-se alunos que chegaram a fazer cursinho dois ou três anos, ou até mais - uma aluna de Medicina fez cursinho seis anos. Já em cursos menos procurados, o percentual dos que fizeram cursinho é menor ${ }^{45}$.

\section{Fraude na autodeclaração:}

Comparou-se o percentual de autodeclarados negros quando do ingresso na UFJF, e outra declaração, feita durante as pesquisas do projeto de Avaliação das Cotas da UFJF. Verificou-se que nos

melhores escolas de ensino médio de MG, 5 são de Juiz de Fora e região, e todas públicas. ${ }^{45}$ Ver Projeto de Avaliação da Política de Cotas na UFJF: Perfil dos Ingressantes, 2014. 
cursos mais procurados, a diferença entre os dois percentuais chega a 30\%, e estima-se que esteja aumentando, na medida em que mais alunos de fora da cidade passam no vestibular ${ }^{46}$. No entanto, a tripla condição de enquadramento nas categorias de cotistas estabelecida na Lei das Cotas (egresso de escolas públicas, renda familiar, autodeclaração) deve contribuir para diminuir estes casos.

Finalizando, a situação ao fim destas análises estatísticas, observa-se mais uma vez o que foi apontado em estudos anteriores, como as diferenças de rendimento, as dificuldades de acompanhar o curso, a desilusão com a universidade, a resistência em abandonar a academia - mesmo se arrastando entre reprovações, trancamentos, e outros “jeitos”. Já se verificou repetidas vezes que isto acontece, principalmente, em cursos da área de Exatas, principalmente nos primeiros períodos ${ }^{47}$.

Deve-se chamar atenção, também, para as novas condições em que é realizado o ingresso nas IFES, seleção pelo ENEM e mobilidade pelo SISU devem aumentar ainda mais a assimetria entre cotistas e não-cotistas. Nos cursos de maior demanda, o que se observa - ainda que com evidências ainda não totalmente claras, é que estão se formando grupos, dentro dos cursos, de acordo com a sua capacidade de acompanhamento. Os alunos mais preparados estão cada vez mais se distanciando dos que ingressaram na universidade beneficiados pelo sistema de cotas. E alunos que ocupam vagas do SISU tendem a ser muito mais exigentes, puxando pela qualidade dos cursos e aumentando a cobrança sobre os docentes ${ }^{48}$.

\footnotetext{
${ }^{46}$ Isto ocorre com frequência em outras IES públicas. Ver o recente caso acontecido na UERJ, e a discussão sobre autodeclaração e fraude em MAIO e SANTOS (2006).

${ }^{47}$ A evasão (abandono e desistência) no BI de Exatas chega a 41\%.

${ }^{48}$ Isto foi observado em uma pesquisa recente feita na Faculdade de Medicina da UFJF, em que alunos entrevistados criticaram duramente algumas deficiências do curso.
} 
A universidade pública parece satisfeita em ter permitido acesso aos menos favorecidos e cumprido sua "obrigação social" expandindo as vagas e multiplicado seus recursos, em um momento em que foi possível convergir tanto o atendimento às demandas do movimento negro quanto o anseio por crescimento, reprimido durante tanto tempo. Isto não basta, a política de cotas foi feita, na quase totalidade das instituições, sem que a academia tivesse se preparado para acolher e tratar com eficiência estes milhares de alunos, da mesma forma que se mostrou eficaz na abertura de seus portões. Não se trata aqui de distribuir mais bolsas, ou criar mais vagas. Trata-se de adaptar e modernizar suas práticas pedagógicas, trata-se de utilizar todos os recursos de produção e transmissão de conhecimento, trata-se de incentivar a reação positiva do corpo discente, trata-se de trabalho, muito trabalho - o trabalho de transformar.

É para isso que existimos.

\section{Ref erências}

ADPF 186. Arguição de Descumprimento de Preceito Fundamental 186 Distrito Federal. SBDP, 2012. Disponível em: <www.sbdp.org.br/arquivos/material/1126_ADPF_186_-_Relatoria.pdff's. Acesso em: 18 Março 2014.

ALBERTI, V.; PEREIRA, A. A. Pesquisando o Movimento Negro no Brasil. Mania de História, 2008. Disponível em: <http://maniadehistoria.wordpress.com/ pesquisando-o-movimento-negro-no-brasil/>. Acesso em: 22 Janeiro 2014.

ALBUQUERQUE, W. R. D.; FRAGA FILHO, W. Uma História do Negro no Brasil. Salvador: Centro de Estudos Afro-Orientais, 2006. Disponivel em: <http:// www.ceao.ufba.br/livrosevideos/pdf/uma\%20historia\%20do\%20negro\%20 no\%20brasil.pdf>. Acesso em: 22 Dezembro 2013.

BERALDO, A. F. D. C. A.; MAGRONE, E. Política de Cotas na UFJF: eficácia e eficiência. Revista de Ciências Humanas UFV, Viçosa, v. 12, n. 2, p. 370-387, Julho/Dezembro 2012.

BERALDO, A. F.; MAGRONE, E. Cotas na Universidade Federal de Juiz de Fora: o começo (2004-2006). In: SANTOS, J. T. D. Cotas nas Universidades - Análise 
dos Processos de Decisão. Salvador: CEAO, 2012. p. 99-134.

BOLOGNA. The Bologna Declaration of 19 June 1999. Europa, 2010. Disponível em: <http://www.ond.vlaanderen.be/hogeronderwijs/bologna/documents/MDC/BOLOGNA_DECLARATION1.pdf>. Acesso em: 12 Julho 2013.

BRASIL. Decreto Reuni, 2007.

EUR-LEX. O Processo de Bolonha: estabelecimento do Espaço Europeu do Ensino Superior. Europa, 2010. Disponível em: <http://europa.eu/legislation_ summaries/education_training_youth/lifelong_learning/c11088_pt.htm>.

FERES JÚNIOR, J.; DAFLON, V. T.; CAMPOS, L. A. Ação afirmativa, raça e racismo: uma análise das ações de inclusão racial nos mandatos de Lula e Dilma. Revista de Ciências Humanas UFV, Viçosa, v. 12, n. 2, p. 399-415, Julho/Dezembro 2012.

G1. Veja frases marcantes do julgamento sobre cotas raciais no Supremo. G1, 2012. Disponível em: <http://g1.globo.com/educacao/noticia/2012/04/ veja-frases-marcantes-do-julgamento-sobre-cotas-raciais-no-supremo.html>. Acesso em: 10 Dezembro 2013.

GUIMARÃES, A. S. A. Acesso de negros às universidades públicas. Cadernos de Pesquisa USP, São Paulo, n. 118, p. 247-268, Março 2003. Disponível em: <http://www.scielo.br/pdf/cp/n118/16836.pdf>. Acesso em: 12 Janeiro 2014.

HASENBALG, C. A.; SILVA, N. D. V. Raça e Oportunidades Educacionais no Brasil. Cadernos de Pesquisa, São Paulo, v. 73, p. 5-12, Maio 1990. Disponível em: <http://educa.fcc.org.br/pdf/cp/n73/n73a01.pdf>.

IBGE. Síntese de Indicadores Sociais. [S.I.]. 2012.

INEP. Censo da Educação Superior - Relatórios Técnicos. INEP, 2013. Disponível em: <http://portal.inep.gov.br/web/censo-da-educacao-superior/resumos-tecnicos>. Acesso em: 23 Dezembro 2013.

LIMA, L. C.; AZEVEDO, M. L. N. D.; CATANI, A. M. O Processo de Bolonha, a avaliação da Educação Superior e algumas considerações sobre a Universidade Nova. Revista da Avaliação da Educação Superior, Campinas, v. 13, p. 7-36, Março 2008. Disponível em: <https://ape.unesp.br/pdi/execucao/artigos/ avaliacao/a02v13n1.pdf>. Acesso em: 12 Julho 2013.

LUNA, M. Entrevista: Joel Rufino dos Santos. História Viva, Osasco, n. 121, p. 14-17, Novembro 2013.

MAIO, M. C.; SANTOS, R. V. Política de cotas raciais, os "olhos da sociedade" e os usos da antropologia: o caso do vestibular da Universidade de Brasília (UnB). 
In: STEIL, C. A. Cotas raciais na Universidade - Um debate. Porto Alegre: Editora da UFRGS, 2006. p. 11-50.

MENDES, G. Decisão da Med. Cautelar em ADPF 186-2 DF. Ações UFSCAR, 2009. Disponível em: <www.acoes.ufscar.br/admin/legislacao/arquivos/arquivo13.pdff $>$. Acesso em: 26 Janeiro 2014.

PINHEIRO, M. 1977: ano de ouro para o funk brasileiro. Brasileiros, 2013. Disponível em: <http://www.revistabrasileiros.com.br/2013/11/21/1977-ano-de-ouro-para-o-funk-brasileiro/\#.U1Eda1ea98E>. Acesso em: 4 Janeiro 2014.

STEIL, C. A. Cotas Raciais na Universidade: um debate. 1a. ed. Porto Alegre: Editora da UFRGS, 2006.

TELLES, E. Racismo à brasileira: uma nova perspectiva sociológica. Rio de Janeiro: Relume Dumará, 2003.

Recebido em 20/10/2014

Aprovado em 03/11/2014 